\title{
Impact of fireworks on ambient air quality: a case study
}

\author{
U. P. Nasir · D. Brahmaiah
}

Received: 15 October 2012/Revised: 28 November 2013/Accepted: 11 January 2014/Published online: 5 February 2014

(C) Islamic Azad University (IAU) 2014

\begin{abstract}
Fireworks activity causes short-term air pollution. The festival of Diwali is celebrated with firecrackers in India during October/November every year. The ambient air quality was assessed in Vadodara city, Gujarat state of India during Diwali festival for the consecutive years 2009, 2010, and 2011. During the festival day, the average concentration of PM10 was increased 35 times compared with a normal day before Diwali. Similarly, concentration of $\mathrm{SO}_{2}$ has increased 23 times and NOx has increased 3 times on the festival day. The diurnal pattern of the above pollutants showed an increase in the night. Air quality index calculated for $24 \mathrm{~h}$ average during Diwali 2009 in two stations exceeded a value of 125 indicating severe air pollution in Vadodara city. It is also confirmed that the yearly pollution load is getting increased in Vadodara city as the air quality index value has a gradual increase from 2009 to 2011. The good correlation coefficient between different pollutants confirmed the firework as the prime source of pollution. Based on PM10 concentration, the highest mortality rate was found to be $30.4 \%$. The shortterm high accumulation of PM10 is a matter of serious concern for city dwellers as it can penetrate deep into the lungs and cause many respiratory and cardiovascular diseases.
\end{abstract}

Keywords Air pollution - Firecrackers - Diwali festival . PM10

U. P. Nasir $(\bowtie) \cdot$ D. Brahmaiah

Central Pollution Control Board, West Zone Office,

Vadodara 390023, Gujarat, India

e-mail: nasirchemistry@yahoo.com

\section{Introduction}

In India, pollution has become a great topic of debate at all levels and especially the air pollution because of urbanization, industrial development, lack of awareness, poor maintenance of motor vehicles, and poor road conditions. Pollutants in the atmosphere arise from two major sources: natural and anthropogenic. It may be surprising to learn that globally, the largest sources of many air pollutants are natural (Chiras 2001). Combustion from motor vehicles and industrial processes by far the major producer of air pollutants (Kupchella and Hyland 1993). Rapid industrialization, urbanization, and development of transport have added impetus to economic development at the cost of environment. In most of the 23 Indian cities with a millionplus population, air pollution levels exceed World Health Organization's recommended health standards. Several cities face severe air pollution problems, with annual average levels of total suspended particulates (TSP) at least three times as high as the WHO standards. A study conducted by the World Bank indicates premature deaths of people in Delhi owing to high levels of air pollution (Review of air quality management system in India).

Diwali is the festival of lights and is celebrated with great enthusiasm all over India every year with bursting of crackers as the most prominent activity. Fireworks contain chemical such as arsenic, sulfur, manganese, sodium oxalate, aluminium and iron dust powder, potassium perchlorate, strontium nitrate, barium nitrate, and charcoal. Burning of these fireworks releases pollutants such as sulfur dioxide $\left(\mathrm{SO}_{2}\right)$, carbon dioxide $\left(\mathrm{CO}_{2}\right)$, carbon monoxide (CO), suspended particles (including particles below $10 \mu \mathrm{m}$ in diameter, i.e., PM10), and several metals such as aluminium, manganese, and cadmium, which are associated with serious health hazards (Ravindra et al. 2003; 
Wang et al. 2007). Additionally, firecrackers often result in serious accidents and lethal injuries (Bull et al. 2001). High concentrations of manganese and chromium have been reported in the scalp hair of manufacturers of fireworks (Sukumar and Subramanian 1992).

Moreno et al. (2007) reported spectacular increase in particulate matter, $\mathrm{SO}_{2}, \mathrm{NOx}$, and metal concentration in ambient air during firework display in Spain. Carranza et al. (2001) have reported significant increase in magnesium and aluminium in aerosol particles related with fireworks. Fleischer et al. (1999) reported that remains of fireworks contained toxic equivalent quantity (TEQ) of octachlorinated dioxins and furans up to $142 \mathrm{ng} / \mathrm{kg}$, as well as hexachlorobenzene in the range of $0.05-1,400 \mathrm{mg} / \mathrm{kg}$. In Oxford (England), an increase in dioxin and furan concentrations (TEQ) by a factor of four occurred during the period of bonfire night, suggesting that bonfire and/or fireworks can be a significant source of trace organic pollutants. Data from Tokyo shows that TSP increased rapidly from $40 \mu \mathrm{g} / \mathrm{m}^{3}$ in the early 1980 s to over $70 \mu \mathrm{g} / \mathrm{m}^{3}$ in the early 1990s; after that TSP has been decreasing or stagnating, but it is becoming an increasing challenge to contain TSP and NOx (Air Pollution Control in the Transportation Sector 2007).

Studies about the air quality during such fireworks display have also been carried out in India. A study conducted on the ambient air quality of the city Lucknow during Diwali festival showed varied concentrations of PM10, $\mathrm{SO}_{2}$, and NOx. On Diwali day, $24 \mathrm{~h}$ average concentration of PM10, $\mathrm{SO}_{2}$, and NOx was found to be higher at 2.49 and 5.67 times for PM10, 1.95 and 6.59 times for $\mathrm{SO}_{2}$, and 1.79 and 2.69 for NOx, when compared with the respective concentration of pre-Diwali and normal day, respectively (Barman et al. 2008). Attri et al. (2001) observed formation of ground level ozone due to burning of color emitting sparklers in Delhi (India) during Diwali festival. In Hisar, India, a study about the short-term variation in air quality during Diwali reported 2-10 times increase in concentrations of PM10, TSP, $\mathrm{NO}_{2}$, and $\mathrm{SO}_{2}$ over a typical winter day (Ravindra et al. 2003). In Hyderabad, India, a study of various metals in firework borne particles during Diwali reported about 1091, 25, 18, and 15 times, respectively, increase in the concentrations of $\mathrm{Ba}, \mathrm{K}, \mathrm{Al}$, and $\mathrm{Sr}$ over a normal day (Kulshrestha et al. 2004). In Thiruvananthapuram, India, a study about the effect of firework display during Diwali on the mass concentration of atmospheric black carbon reveals over three times increase compared with normal days (Babu and Moorthy 2001). Mandal et al. (2012) indicated that there was a significant increase in the concentration of pollutants such as PM10 and $\mathrm{SO}_{2}$ in the ambient air of Delhi during the day of Diwali 2012. Singh et al. (2010) observed that the levels of different pollutants observed during Diwali were found to be higher due to adverse meteorological conditions, i.e., decrease in $24 \mathrm{~h}$ average mixing height, temperature, and wind speed.

Even though firework activity during Diwali festival in Gujarat state, India, is more prominent, no study has been reported in the state to understand the variation of air quality during the festival. Hence, as per the guidelines of Central Pollution Control Board, Government of India, a study has been conducted every year to understand the short-term variation of air quality during the Diwali festival time. The objective of present study is to assess the shortterm variation in the ambient concentration of $\mathrm{SO}_{2}$, nitrogen dioxide (as $\mathrm{NO}_{2}$ ), and respirable particulate as PM10 associated with firework events at different location in Vadodara city, Gujarat, India. The present paper describes the variation of air quality in the Diwali festival during the consecutive year, 2009, 2010, and 2011. The paper also tries to compare the pollution load in Vadodara city compared with different studies conducted in other cities of India. It is also aimed to calculate the air quality index (AQI) for Vadodara city to categorize according to the pollution load. Three locations in the city were selected for the study and monitoring was carried out in a normal day before Diwali and during the festive day of Diwali for 24 with $8 \mathrm{~h}$ interval of sampling.

\section{Materials and methods}

A total of three sampling sites were selected in Vadodara city $\left(22^{\circ} 18^{1} 38.00 \mathrm{~N}, 73^{\circ} 10^{1} 50.76 \mathrm{E}\right)$ on the basis of different activities such as population, vehicular transport, wind direction (Fig. 1). Fatehgunj (Station A) is a residential area in the heart of the city, which has been selected because of high intensity of vehicular transport. The M. S. University was selected as sensitive area (Station B). Harinagar (Station C) was selected as the hot spot. It is $6 \mathrm{~km}$ away from the Vadodara railway station, which has been selected because of high population density. The monitoring was carried out in three shifts in a normal day before Diwali festival and on Diwali festival day of the year 2009, 2010, and 2011. The first shift is from 6 am to $2 \mathrm{pm}$, second shift from $2 \mathrm{pm}$ to $10 \mathrm{pm}$, and third from $10 \mathrm{pm}$ to $6 \mathrm{am}$.

APM-460 respirable dust samplers (RDS) with provision for gaseous sampling (APM-411 Envirotech, New Delhi) were used for measuring the concentrations of PM10, NOx, and $\mathrm{SO}_{2}$ in the air. The sampling inlet was placed $\sim 5 \mathrm{~m}$ above the ground level. Atmospheric air was drawn through the cyclone and $20 \times 25 \mathrm{~cm}$ glass fiber filter (GFF) paper sheet at a flow rate of $0.8-1.2 \mathrm{~m}^{3} \mathrm{~min}^{-1}$. The filter paper was changed at an interval of $8 \mathrm{~h}$ covering three samples per day. $\mathrm{SO}_{2}$ was analyzed following Lodge 21 by employing the West-Gaeke method on 


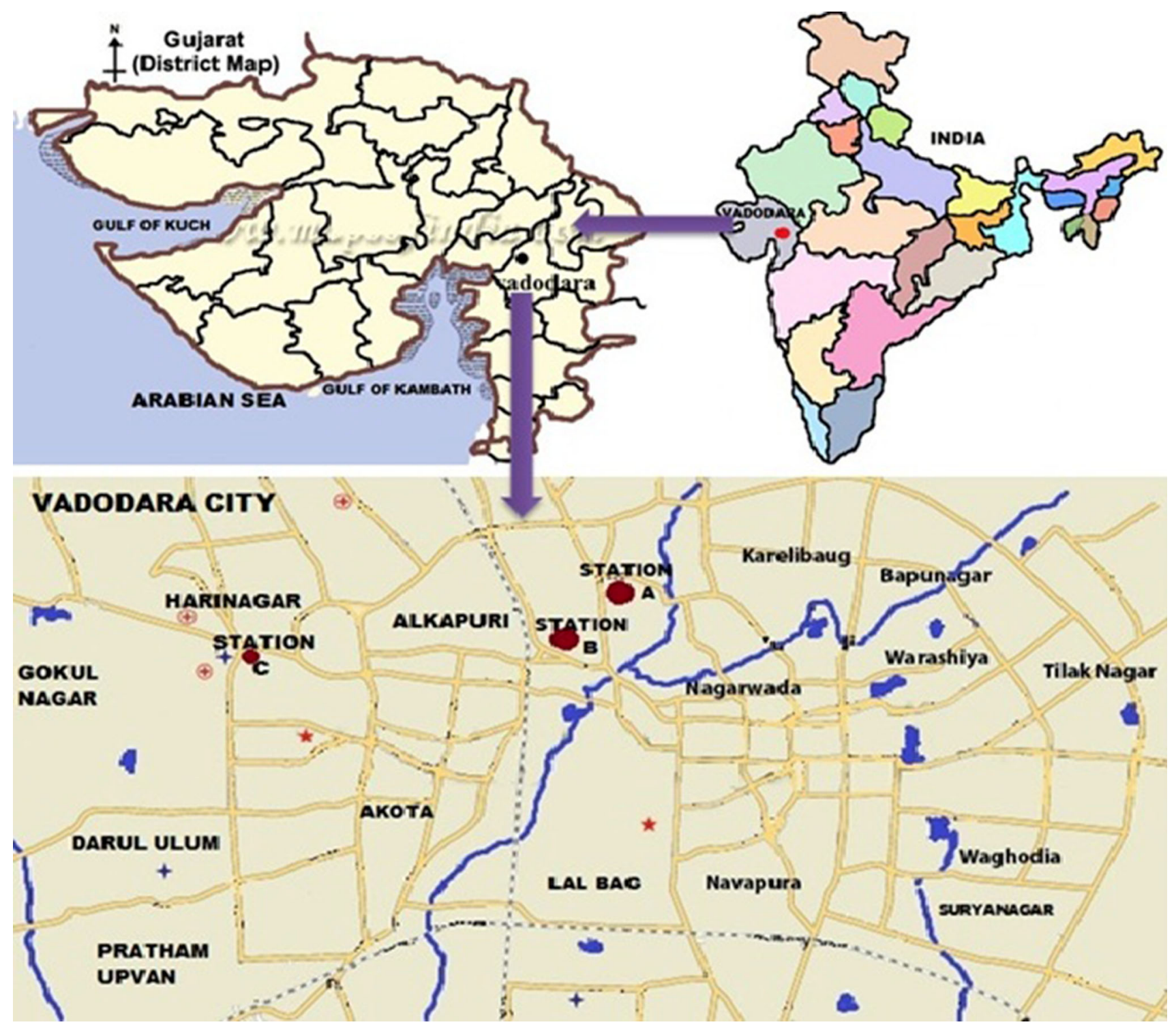

Fig. 1 Map of Vadodara city showing the ambient air monitoring stations

Spectronic-21 spectrophotometer at wavelength of $560 \mathrm{~nm}$. NOx was also analyzed following Lodge21 employing the Jacob-Hochheiser modified method on the above spectrophotometer at wavelength of $540 \mathrm{~nm}$.

\section{Results and discussion}

Burning of sulfur nitrates, magnesium, aluminum, paper, and host of other materials contained in crackers and fireworks produces air pollution during Diwali. The full composition and the relative concentration of the various gaseous vapors and particulate pollutants emitted are not known. However, $\mathrm{SO}_{2}, \mathrm{NOx}$, and particulate matter (especially PM10) are of special interest, as they are known to be potentially injurious to the respiratory passages and other health effects. The metrological parameters (Table 1) during Diwali and after Diwali were almost identical and can be used for the comparison of the air quality data. Further, the atmosphere was stable with no inversion, which supports a low lapse rate. During the monitoring period, the weather was sunny without any clouds cover.

The present study indicates the air pollutant concentrations and AQI at three monitoring sites of Vadodara city. Tables 2, 3, and 4 represent the concentration of PM10, $\mathrm{SO}_{2}$, and NOx at these locations in a normal day before Diwali and on Diwali day. The data were used to calculate ambient AQI of each stations in both normal and Diwali day. 
Table 1 Meteorological parameters recorded during the monitoring period

\begin{tabular}{lllllll}
\hline Year & $\begin{array}{l}\text { Maximum }\left({ }^{\circ} \mathrm{C}\right) \\
\text { temperature }\end{array}$ & $\begin{array}{l}\text { Minimum }\left({ }^{\circ} \mathrm{C}\right) \\
\text { temperature }\end{array}$ & $\begin{array}{l}\text { Average }\left({ }^{\circ} \mathrm{C}\right) \\
\text { temperature }\end{array}$ & $\begin{array}{l}\text { Average relative } \\
\text { humidity }(\%)\end{array}$ & $\begin{array}{l}\text { Average } \\
\text { visibility }(\mathrm{km})\end{array}$ & $\begin{array}{l}\text { Average wind } \\
\text { speed }(\mathrm{km} / \mathrm{h})\end{array}$ \\
\hline 2009 & 29 & 18 & 23.7 & 70 & 4.2 & 11.7 \\
2010 & 32.4 & 23.5 & 27.6 & 72 & 3.7 & 9.3 \\
2011 & 36 & 19 & 28.6 & 51 & 3.5 & 2 \\
\hline
\end{tabular}

Table 2 Concentration of PM10 in the ambient air of Vadodara city during Diwali festival

\begin{tabular}{|c|c|c|c|c|c|c|c|}
\hline \multirow[t]{2}{*}{ Stations } & \multirow[t]{2}{*}{ Time } & \multicolumn{3}{|c|}{ Pre-Diwali (normal day) } & \multicolumn{3}{|c|}{ Diwali } \\
\hline & & $\begin{array}{l}2009 \\
\text { PM10 }\left(\mu \mathrm{g} / \mathrm{m}^{3}\right)\end{array}$ & 2010 & 2011 & 2009 & 2010 & 2011 \\
\hline \multirow[t]{3}{*}{ Harinagar } & 6 am to $2 \mathrm{pm}$ & 147.6 & 108 & 138 & 161.9 & 88 & 118 \\
\hline & $2 \mathrm{pm}$ to $10 \mathrm{pm}$ & 58.1 & 128 & 135 & 699.5 & 155 & 260 \\
\hline & $10 \mathrm{pm}$ to $6 \mathrm{am}$ & 20.2 & 113 & 134 & 349.4 & 173 & 320 \\
\hline \multirow[t]{3}{*}{ Fatehgunj } & 6 am to $2 \mathrm{pm}$ & 172.1 & 193 & 162 & 204.6 & 147 & 156 \\
\hline & $2 \mathrm{pm}$ to $10 \mathrm{pm}$ & 144.7 & 159 & 149 & 280.8 & 163 & 218 \\
\hline & $10 \mathrm{pm}$ to $6 \mathrm{am}$ & 88.1 & 133 & 117 & 456.7 & 144 & 291 \\
\hline \multirow[t]{3}{*}{ MSU } & 6 am to $2 \mathrm{pm}$ & 124.9 & 135 & 77 & 99.9 & 68 & 106 \\
\hline & $2 \mathrm{pm}$ to $10 \mathrm{pm}$ & 65.4 & 134 & 110 & 199.3 & 109 & 147 \\
\hline & $10 \mathrm{pm}$ to $6 \mathrm{am}$ & 26.0 & 115 & 103 & 334.1 & 171 & 247 \\
\hline
\end{tabular}

Table 3 Concentration of $\mathrm{SO}_{2}$ in the ambient air of Vadodara city during Diwali festival

\begin{tabular}{|c|c|c|c|c|c|c|c|}
\hline \multirow[t]{2}{*}{ Station } & \multirow[t]{2}{*}{ Time } & \multicolumn{3}{|c|}{ Pre-Diwali (normal day) } & \multicolumn{3}{|l|}{ Diwali } \\
\hline & & $\begin{array}{l}2009 \\
\mathrm{SO}_{2}\left(\mu \mathrm{g} / \mathrm{m}^{3}\right)\end{array}$ & 2010 & 2011 & 2009 & 2010 & 2011 \\
\hline \multirow[t]{3}{*}{ Harinagar } & 6 am to $2 \mathrm{pm}$ & BDL & BDL & BDL & 38.75 & BDL & 4.94 \\
\hline & $2 \mathrm{pm}$ to $10 \mathrm{pm}$ & BDL & BDL & BDL & 87.62 & 22.77 & 11.21 \\
\hline & $10 \mathrm{pm}$ to $6 \mathrm{am}$ & $\mathrm{BDL}$ & BDL & BDL & 81.59 & 29.57 & 16.66 \\
\hline \multirow[t]{3}{*}{ Fatehgunj } & 6 am to $2 \mathrm{pm}$ & BDL & BDL & BDL & 53.22 & BDL & 4.11 \\
\hline & $2 \mathrm{pm}$ to $10 \mathrm{pm}$ & BDL & BDL & BDL & 50.96 & 10.55 & 5.49 \\
\hline & $10 \mathrm{pm}$ to $6 \mathrm{am}$ & BDL & BDL & BDL & 68.56 & 17.26 & 15.57 \\
\hline \multirow[t]{3}{*}{ MSU } & 6 am to $2 \mathrm{pm}$ & BDL & BDL & BDL & 46.68 & BDL & BDL \\
\hline & $2 \mathrm{pm}$ to $10 \mathrm{pm}$ & BDL & BDL & BDL & 38.87 & 5.79 & 6.29 \\
\hline & $10 \mathrm{pm}$ to $6 \mathrm{am}$ & BDL & BDL & BDL & 53.63 & 19.81 & 6.31 \\
\hline
\end{tabular}

$B D L$ below detectable limit

\section{PM10}

There is now growing concern all over the world about particulate matter of size 10 and $2.5 \mu \mathrm{m}$ (PM10 and 2.5) or less. The WHO has classified these as thoracic particles because these are respirable and because of their small size, get lodged deep down in the lower respiratory track. These particles exacerbate cardiac and respiratory problems among the primary pollutants. National level standard for $\mathrm{RSPM} / \mathrm{PM} 10$ annual average is $60 \mu \mathrm{g} / \mathrm{m}^{3}$ and $24 \mathrm{~h}$ average is $100 \mu \mathrm{g} / \mathrm{m}^{3}$.
During the study period, the PM10 varied from 20 to $699 \mu \mathrm{g} / \mathrm{m}^{3}$. The maximum concentration was at Harinagar station during Diwali 2009, and the minimum was observed at the same station on a normal day. The highest concentration is on the second shift and the lowest concentration is in the third shift. The drastic increase in PM10 concentration to 35 times of a normal day in Diwali day indicated contribution of firecrackers to pollution load in Harinagar station. The silent zone M. S. University campus also recorded a deep rise in PM10 concentration from 26 to $334 \mu \mathrm{g} / \mathrm{m}^{3}$. The ambient air concentration of PM10 was 
Table 4 Concentration of NOx in the ambient air of Vadodara city during Diwali festival

\begin{tabular}{|c|c|c|c|c|c|c|c|}
\hline \multirow[t]{2}{*}{ Stations } & \multirow[t]{2}{*}{ Time } & \multicolumn{3}{|c|}{ Pre-Diwali (normal day) } & \multicolumn{3}{|c|}{ Diwali } \\
\hline & & $\begin{array}{l}2009 \\
\text { NOx }\end{array}$ & 2010 & 2011 & 2009 & 2010 & 2011 \\
\hline \multirow[t]{3}{*}{ Harinagar } & 6 am to $2 \mathrm{pm}$ & 6.7 & 22.2 & 16.3 & 16.5 & 12.9 & 12.9 \\
\hline & $2 \mathrm{pm}$ to $10 \mathrm{pm}$ & 7.9 & 21.0 & 27.7 & 21.0 & 17.1 & 20.6 \\
\hline & $10 \mathrm{pm}$ to $6 \mathrm{am}$ & 10.8 & 26.2 & 29.7 & 18.5 & 27.7 & 19.6 \\
\hline \multirow[t]{3}{*}{ Fatehgunj } & 6 am to $2 \mathrm{pm}$ & 8.7 & 26.2 & 26.4 & 26.9 & 13.5 & 19.2 \\
\hline & $2 \mathrm{pm}$ to $10 \mathrm{pm}$ & 14.6 & 27.6 & 32.1 & 28.7 & 20.5 & 28.9 \\
\hline & $10 \mathrm{pm}$ to $6 \mathrm{am}$ & 13.1 & 17.5 & 31.9 & 38.7 & 23.5 & 18.2 \\
\hline \multirow[t]{3}{*}{ MSU } & 6 am to $2 \mathrm{pm}$ & 14.6 & 10.8 & 10.0 & 22.4 & 10.0 & 6.9 \\
\hline & $2 \mathrm{pm}$ to $10 \mathrm{pm}$ & 11.6 & 7.1 & 22.0 & 27.1 & 12.7 & 4.5 \\
\hline & $10 \mathrm{pm}$ to $6 \mathrm{am}$ & 13.5 & 18.7 & 37.1 & 33.4 & 14.7 & 16.6 \\
\hline
\end{tabular}

observed more than the stipulate standard values at all three sites during Diwali day. According to Simkhada et al. (2005), rain has a positive effect in bringing down the particulate concentration. The no rain condition in $\mathrm{Va}-$ dodara city during Diwali might have increased the level of PM10 concentration.

The exposure to particulate matter is reported to have caused chronic respiratory and cardiovascular diseases, alter host defense, damage lung tissue, lead to premature death and contribute to cancer (Nkwocha and Egejuru 2008; Seaton et al. 1995; Bates 1996; Pope et al. 2002; Giri et al. 2006). Recent epidemiological studies clearly establish the relation between the harmful effects on human health and mortality with increased concentration of atmospheric particulates (Thakur 2010). Lippmann (1997) estimated that the total daily mortality increased by approximately $1 \%$ for every $10 \mathrm{mg} \mathrm{m}^{-3}$ increase in PM10 concentration. Keeping in view this fact and considering NAAQS as a standard, we predicted the mortality rate (\%) for all the locations which exceeded the NAAQS value. Mortality rate in Harinagar during 2009 was calculated to be highest $(30.4 \%)$, and minimum was in M. S. University campus in $2010(1.6 \%)$. The effect of PM10 depends on the mass and number concentration, shape and size and the composition and concentration of other inorganic and organic pollutants associated with it. In the present study, inhalation/deposition fluxes of the average concentration of particulate matter (RSPM) were calculated daily by considering ventilation rates of air $20 \mathrm{~m}^{3} \mathrm{day}^{-1}$ for $70 \mathrm{~kg}$ adult and $6 \mathrm{~m}^{3}$ day $^{-1}$ for 2 year child suggested by LaGrega et al. (1994) and followed by Khodja et al. (2007) for human risk characterization. The average concentrations of the PM10 on Diwali day in three stations were used to calculate the inhalation flux. Calculations revealed the maximum inhalation of PM10 by $70 \mathrm{~kg}$ adult is $8,072 \mu \mathrm{g} \mathrm{day}^{-1}$ and $2,421 \mu \mathrm{g} \mathrm{day}^{-1}$ for 2 year child. Normally, it would be below 2,000 and $600 \mu \mathrm{g} \mathrm{day}^{-1}$, respectively (value calculated by considering the NAAQS, i.e., $100 \mu \mathrm{g} \mathrm{m}^{-3}$ ) (CPCB 2009).

Sulfur dioxide $\left(\mathrm{SO}_{2}\right)$

In general, firecrackers contain $75 \%$ potassium nitrate, $15 \%$ carbon (C), and $10 \%$ sulfur (S). Potassium nitrate is a strong oxidizing agent, when burnt with $\mathrm{C}$ and $\mathrm{S}$, it release gases such as $\mathrm{CO}_{2}$ and $\mathrm{SO}_{2}$. The average concentration of $\mathrm{SO}_{2}$ before Diwali (normal day) was found to be below detectable limit. During Diwali 2009, the $\mathrm{SO}_{2}$ concentration has increased up to $87.62 \mu \mathrm{g} / \mathrm{m}^{3}$ at Harinagar station. Diurnal pattern of $\mathrm{SO}_{2}$ concentration showed a significant increase in second shift (Table 2), which seems to be associated with increased firework events. On the other hand, the same station on a normal day in the same time period has below detectable amount. Even the sensitive site, M. S. University campus has also reported a concentration of $75.29 \mu \mathrm{g} / \mathrm{m}^{3}$ during 2009 Diwali day. High levels of $\mathrm{SO}_{2}$ are particularly dangerous in the presence of particulate matter, because it slowly adsorbs on fine atmospheric particles and can be transported very deep into lungs, and therefore staying there for a long time. Due to their very long residence time and acidic character, they can cause serious damage to the lungs tissue (edema). WHO (1987) and other studies (Dockery et al. 1992) have shown that of among the particles of diverse composition, sulfates have the worst health impact, which also stay in air for long time.

\section{Nitrogen dioxide (NOx)}

The concentration of NOx in different stations of Vadodara city on a normal day and Diwali festival day is given in Table 4. Even though the concentration of NOx is with in the range of NAAQ standards, there is a slight increase in the concentration on Diwali day comparing to a normal day. More over, there is an increase in NOx concentration 
Table 5 Correlation among the monitored pollutants in different stations Vadodara

\begin{tabular}{|c|c|c|c|c|c|c|c|c|c|}
\hline $\begin{array}{l}\text { NOx } \\
(2010)\end{array}$ & $\begin{array}{l}\text { NOx } \\
(2010)\end{array}$ & $\begin{array}{l}\text { NOx } \\
(2009)\end{array}$ & $\begin{array}{l}\mathrm{SO}_{2} \\
(2011)\end{array}$ & $\begin{array}{l}\mathrm{SO}_{2} \\
(2010)\end{array}$ & $\begin{array}{l}\mathrm{SO}_{2} \\
(2009)\end{array}$ & $\begin{array}{l}\text { PM10 } \\
\text { (2011) }\end{array}$ & $\begin{array}{l}\text { PM10 } \\
\text { (2010) }\end{array}$ & $\begin{array}{l}\text { PM10 } \\
\text { (2009) }\end{array}$ & $\begin{array}{l}\text { Pearson's } \\
\text { correlation }\end{array}$ \\
\hline & & & & & & & & 1 & PM10 (2009) \\
\hline & & & & & & & 1.00 & 0.60 & PM10 (2010) \\
\hline & & & & & & 1.00 & 0.83 & 0.74 & PM10 (2011) \\
\hline & & & & & 1.00 & 0.83 & 0.62 & 0.85 & $\mathrm{SO}_{2}(2009)$ \\
\hline & & & & 1.00 & 0.83 & 0.95 & 0.76 & 0.75 & $\mathrm{SO}_{2}(2010)$ \\
\hline & & & 1.00 & 0.83 & 0.77 & 0.89 & 0.60 & 0.75 & $\mathrm{SO}_{2}(2011)$ \\
\hline & & 1.00 & 0.15 & 0.12 & -0.04 & 0.31 & 0.34 & 0.16 & NOx (2009) \\
\hline & 1.00 & 0.15 & 0.88 & 0.78 & 0.69 & 0.89 & 0.69 & 0.49 & NOx (2010) \\
\hline 1.00 & 0.62 & 0.16 & 0.36 & 0.44 & 0.49 & 0.59 & 0.77 & 0.48 & NOx (2011) \\
\hline
\end{tabular}

in the second shift, where the cracking of fireworks is maximum, which indicates the contribution of fireworks toward ambient NOx level during Diwali festival. But in the year 2010, the concentration of NOx is comparatively lower on Diwali day than a normal day. This may be due to less contribution from vehicular source on Diwali day.

The highest concentration of NOx was measured at station Fatehgunj during the day of Diwali 2009. Similarly, the silent zone of M. S. University camps has recorded the lowest value of NOx during a normal day of the year 2011 . The health effects of $\mathrm{NO}_{2}$ have been reviewed in various studies (Ackermann-liebrich et al. 1999).

\section{Statistical analysis}

Correlation analysis was carried out for PM10 with different air quality parameters for air pollution study in Delhi (Tiwari et al. 2012). Inter correlations of the monitored pollutants are calculated for Diwali festival day, and the correlation matrix (for Pearson correlation coefficient) is presented in Table 5.

The concentration of $\mathrm{SO}_{2}$ in a normal day before Diwali is below detectable limit, which indicates that there is no correlation for $\mathrm{SO}_{2}$ with PM10 and NOX. The increase in concentration of $\mathrm{SO}_{2}$ in the Diwali day itself shows its contribution from fireworks. More over, the strong correlation between PM10 and $\mathrm{SO}_{2}$ confirmed the contribution of pollutants from fireworks activity to the atmosphere. A similar correlation has seen between $\mathrm{SO}_{2}$ and $\mathrm{NOx}$ in the year 2010 and 2011, which emphasizes its contribution from festival of Diwali. But there is a negative correlation between $\mathrm{SO}_{2}$ and NOx in the year 2009, and the correlation between PM10 and NOx is poor. It suggests that the abnormal high concentration of PM10 in the year 2009 is not only due to fireworks, but is also due to different activities such massive crowding which spread the particulates from earth to atmosphere. A correlation analysis has also conducted to know the interrelation between the
Table 6 Rating scale of air quality index

\begin{tabular}{lll}
\hline SI no & Index value & Remarks \\
\hline 1 & $0-25$ & Clean air (CA) \\
2 & $26-50$ & Light air pollution (LAP) \\
3 & $51-75$ & Moderate air pollution (MAP) \\
4 & $76-100$ & Heavy air pollution (HAP) \\
5 & Above 100 & Severe air pollution (SAP) \\
\hline
\end{tabular}

stations. It indicates that the correlation of $\mathrm{SO}_{2}$ between different stations on Diwali day in the three consecutive years is very high with a correlation coefficient of one.

Air quality index (AQI)

AQI is developed to provide the information about air quality. AQI was introduced by the environmental protection agency (EPA) in USA to measure the levels of pollution due to major air pollutants. It is one of the important tools available for analyzing and representing air quality status uniformly. The concentrations of the major pollutants are monitored and subsequently converted into AQI using standard formulae and rating scale was also calculated (Table 6). In the present investigation, the PM10, NOx, and $\mathrm{SO}_{2}$ levels at all three selected locations have been used to calculate the AQI. The higher value (above 125) of an index refers to a great level of air pollution (severely polluted).

The AQI was calculated by the following formula:

$$
\begin{aligned}
\mathrm{AQI}= & 100 \\
& \times \frac{\text { Observed mean concentration of a pollutant }}{\text { Standard for the respective pollutant }}
\end{aligned}
$$

The data obtained from monitoring of ambient air during a normal day and Diwali day in the study area is converted to AQI for different stations and has shown graphically in Fig. 2. The highest index value of 278 was reported by the 
Fig. 2 Air quality index values for different stations of Vadodara city, Gujarat, India
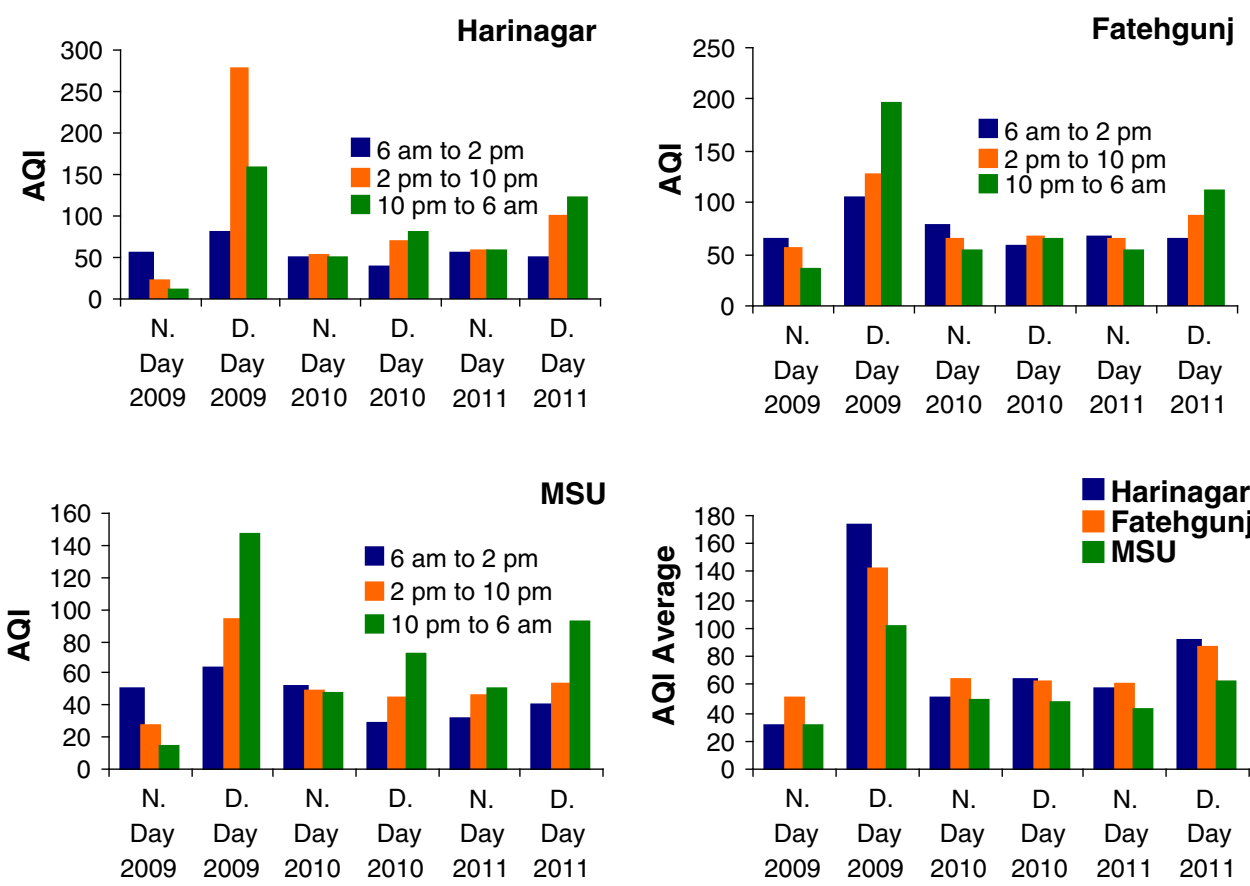

station Harinagar during Diwali 2009. It is also noticed that the yearly pollution load is getting increased, as the AQI value has a gradual increase from 2009 to 2011 in a normal day. The location Harinagar and Fatehgunj has a moderate pollution in a normal day of the year 2011 and increased to heavy pollution at Diwali day. Even the sensitive area M. S. University has also recorded moderate to heavy pollution during the festival time.

\section{Conclusion}

Display of fireworks with loud explosive, crackers, etc., during Diwali celebration causes enormous though shortlived air pollution. The concentration of the pollutants is very high on Diwali day compared with the normal day. The good correlation coefficient between different pollutants confirmed the firework as the prime source of pollution. The concentration of $\mathrm{SO}_{2}, \mathrm{NOx}$, and PM10 in the ambient air has shown increase, as the crackers start bursting. The Harinagar station has recorded the highest PM10 concentration of $699.5 \mathrm{mg} / \mathrm{m}^{3}$ on Diwali day. There is an abnormal increase of $\mathrm{SO}_{2}$ concentration in Diwali day in most of the station, which is directly accounted from firecrackers. Highest concentration of pollutants was noted at Harinagar, which seems to be related with the dense population. The AQI calculated from different pollutants is also high in all the stations in Diwali day, with highest index value of 278 , which indicates severe air pollution. It is also confirmed that the yearly pollution load is getting increased in Vadodara city as the AQI value has a gradual increase from 2009 to 2011 . The short-term exposure of these pollutants above the permissible allowable limits can increase the likelihood of acute health effects. Based on PM10 concentration, the highest mortality rate was found to be $30.4 \%$. Hence, there is a need exist to determine this proportion and to control this pollution.

Acknowledgments The authors wish to express their gratitude to B R Naidu, Zonal Officer, Central Pollution Control Board, Zonal office Vadodara for allowing doing the research work.

\section{References}

Ackermann-liebrich U, Rapp R In: Holgate ST, Samet JM, Koren HS, Maynard RL (1999) Air pollution and health. London, Academic Press, pp 559-584

Air Pollution Control in the Transportation Sector (2007) Third phase research report of the urban environmental management project, Institute for Global Environmental Strategies. Sato Printing Co., Ltd., Yokohama

Attri AK, Kumar U, Jain VK (2001) Formation of ozone by fireworks. Nature 411:1015

Babu SS, Moorthy KK (2001) Anthropogenic impact on aerosol black carbon mass concentration at a tropical coastal station: a case study. Curr Sci 81:1208-1214

Barman SC, Singh R, Negi MPS, Bhargava SK (2008) Ambient air quality of Lucknow City (India) during use of fireworks on Diwali festival. Environ Monit Assess 137:495-504

Bates DV (1996) Particulate air pollution. Thorax 51:S3-S8

Bull MJ, Agran P, Gardner HG, Laraque D, Pollack SH, Smith GA, Spivak HR, Tenenbein M, Brenner RA, Bryn S, Neverman C, Schieber RA, Stanwick R, Tinsworth D, Garcia V, Tanz R, 
Newland H (2001) American Academy of Pediatrics. Committee on injury and poison prevention. Fireworks-related injuries to children. Pediatrics 108:190-191

Carranza JE, Fisher BT, Yoder GD, Hahan DW (2001) On-line analysis of ambient air aerosols using laser-induced breakdown spectroscopy. Spectrochim Acta, Part B 56:851-864

Chiras DD (2001) Environmental science: creating a sustainable future, 6th edn. Jones and Bartlett Publishers, Canada

CPCB (2009) National ambient air quality standards, Central Pollution Control Board, Gazette Notification, New Delhi

Dockery DW, Schwartz J, Spengler JD (1992) Air pollution and daily mortality: associations with particulates and acid aerosols. Environ Res 59:362-373

Fleischer O, Wichmann H, Lorenz W (1999) Release of polychlorinated dibenzo-p-dioxins and dibenzofurans by setting off fireworks. Chemosphere 39:925-932

Giri D, Murthy K, Adhikary PR, Khanal SN (2006) Ambient air quality of Kathmandu Valley as reflected by atmospheric participate matter concentrations (PM10). Int J Environ Sci Technol 3(4):403-410

Khodja HA, Belaala A, Debbih W, Habbas B, Boumagoura N (2007) doi:10.1007/s10661-007-9792-1

Kulshrestha UC, Rao TN, Azhaguvel S, Kulshrestha MJ (2004) Emissions and accumulation of metals in the atmosphere due to crackers and sparkles during Diwali festival in India. Atmos Environ 38:4421-4425

Kupchella CE, Hyland MC (1993) Environmental science, living within the system of nature, Ke-3 Ed. Prentice-Hall International, Inc, New Jersey

LaGrega MD, Buckingham PL, Evans JC (1994) Toxicological data. In: Hazardous waste management, Apendix B, Publisher McGraw-Hill, Singapore

Lippmann M (1997) USEPA standards for particulate matter and ozone. In: Hester RE, Harrison R (eds) Issues in environmental science and technology. Royal Society of Chemistry UK, 10:75-99 (1998)

Mandal P, Prakash M, Bassin JK (2012) Impact of Diwali celebration on urban air and noise quality in Delhi city, India. Environ Monit Assess 184:209-215
Moreno T, Querol X, Alastuey A, Minguillon MC, Pey J, Rodriguez S, Miro JV, Felis C, Gibbons W (2007) Recreastional atmospheric pollution episodes: inhalable metalliferous particles from firework displays. Atmos Environ 41:913-922

Nkwocha EE, Egejuru RO (2008) Effects of industrial air pollution on the respiratory health of children. Int J Environ Sci Technol 5(4):509-516

Pope CAIII, Burnett R, Thun TMJE, Calle E, Krewski D, Kazuhiko I, Thurston GD (2002) Lung cancer, cardiopulmonary mortality, and long term exposure to fine particulate air pollution. J Am Med Assoc 287:1132-1141

Ravindra K, Mor S, Kaushik CP (2003) Short-term variation in air quality associated with firework events: a case study. J Environ Monit 5:260-264

Seaton A, MacNee W, Donaldson K, Godden D (1995) Particulate air pollution and acute health effects. Lancet 345:176-178

Simkhada K, Murthy KV, Khanal SN (2005) Assessment of ambient air quality in Bishnumati corridor, Kathmandu metropolis. Int J Environ Sci Technol 2(3):217-222

Singh DP, Gadi R, Mandal TK, Dixit CK, Singh K, Saud T, Singh N, Gupta PK (2010) Study of temporal variation in ambient air quality during Diwali festival in India. Environ Monit Assess 169:1-13

Sukumar A, Subramanian R (1992) Trace elements in scalp hair of manufacturers of fireworks from Sivakasi, Tamil Nadu. Sci Total Environ 114:161-168

Thakur B (2010) Air pollution from fireworks during festival of lights (Diwali) in Howrah, India-a case study. Atmósfera 23(4): 347-365

Tiwari S, Chate DM, Srivastava MK, Safai PD, Srivastava AK, Bisht DS, Padmanabhamurty B (2012) Statistical evaluation of PM10 and distribution of PM 1, PM 2.5, and PM10 in ambient air due to extreme fireworks episodes (Deepawali festivals) in megacity Delhi. Nat Hazards 61(2):521-531

Wang Y, Zhuang G, Xua C, An Z (2007) The air pollution caused by the burning of fireworks during the lantern festival in Beijing. Atmos Environ 41:417-431

WHO (1987) Air quality Guidelines for Europe, WHO regional Publications, Europien Series No. 23, Regional Office for Europe, World Health Organization, Copenhagen 